Archive for

Organic Chemistry

Arkivoc 2017, part ii, 313-323

\title{
Synthesis, lipase catalyzed kinetic resolution, and determination of the absolute configuration of enantiomers of the Morita-Baylis-Hillman adduct 3- hydroxy-2-methylenebutanenitrile
}

\author{
Daniel J. Strub, ${ }^{\mathrm{a}, \mathrm{b}, *}$ Agata Garboś, ${ }^{\mathrm{a}}$ and Stanisław Lochyński ${ }^{\mathrm{a}, \mathrm{c}}$ \\ ${ }^{a}$ Department of Bioorganic Chemistry, Faculty of Chemistry, Wrocław University \\ of Science and Technology, Wyb. Wyspiańskiego 27, 50-370 Wrocław, Poland \\ ${ }^{b}$ Liquid Technologies, Chełmońskiego 12, 51-630 Wrocław, Poland \\ c Institute of Cosmetology, Wrocław College of Physiotherapy, Kościuszki 4, 50-038 Wrocław, Poland \\ Email:daniel.strub@pwr.edu.pl
}

\section{Dedicated to Prof. Jacek Młochowski on the occasion of his $80^{\text {th }}$ birthday}

Received 07-20-2016

Accepted 09-15-2016

Published on line 09-29-2016

\section{Abstract}

3(RS)-Hydroxy-2-methylenebutanenitrile was synthesized from acetaldehyde and acrylonitrile with DABCO as a catalyst. Optimization of the reaction conditions was conducted because some literature procedures were not reproducible. Asymmetric transesterification of the Morita-Baylis-Hillman adduct was carried out using ten lipases. The hydroxyl-nitrile was also esterified chemically and subjected to enzymatic hydrolysis with the same set of enzymes. The best results were obtained with lipase from Candida antarctica and Novozyme 435. The absolute configuration of an optically pure hydroxyl-nitrile was determined by Mosher's method.

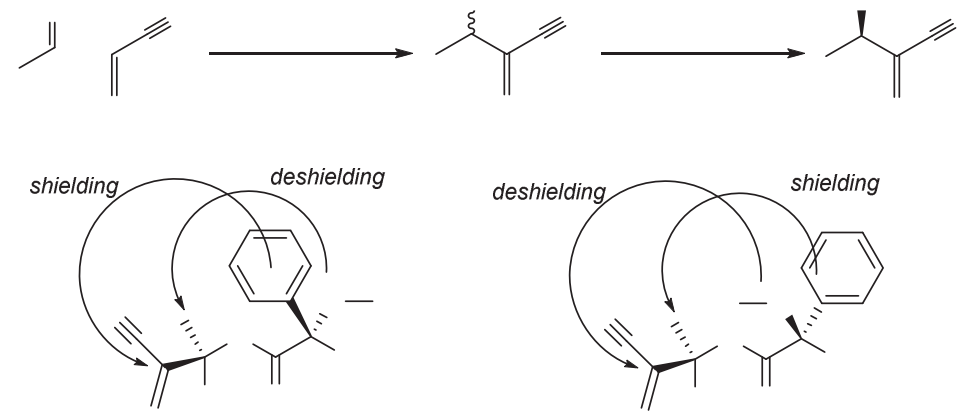

Keywords: Morita-Baylis-Hillman reaction, transesterification, hydrolysis, lipases, biocatalysis, stereochemistry 


\section{Introduction}

The Morita-Baylis-Hillman (MBH) reaction is a useful tool for the synthesis of multifunctionalized compounds from electrophiles and activated alkenes (Scheme 1).

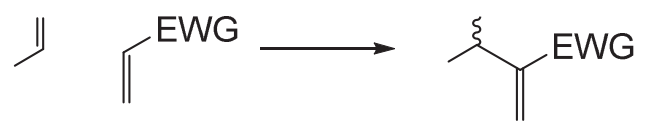

Scheme 1. General scheme of the $\mathrm{MBH}$ reaction.

Since the end of the 1960s many modifications of the Morita-Baylis-Hillman reaction have been developed including asymmetric versions with application of organocatalysts ${ }^{1}$ such as chiral phosphoroorganic compounds, ${ }^{2-4}$ chiral Brønsted acids ${ }^{5}$ or thiourea derivatives. ${ }^{3,6-8}$ Biocatalysts $^{9-11}$ have also been employed as chiral auxiliaries in $\mathrm{MBH}$ reactions, but in general they are less effective in terms of both substrate conversion and stereoselectivity. Our previous research focused on the synthesis and evaluation of biological activities of novel terpenoid derivatives. ${ }^{12-15}$ We have focused recently on the possibility of using $\mathrm{MBH}$ adducts in the synthesis of novel $\delta$-lactones with potential olfactory properties. We chose 3-(RS)-hydroxy-2methylenebutanenitrile $\mathbf{1}(\boldsymbol{R S})$ as a model substrate for further studies. The use of simple aldehydes and activated alkenes provides a good model for the optimization of $\mathrm{MBH}$ reactions in various environments. ${ }^{16-18}$ Most studies of this sort have been carried out using ring-substituted benzaldehydes.

$\beta$-Hydroxy-nitriles are less commonly known to possess interesting aroma profiles but there is some evidence of their usefulness as fragrance agents. ${ }^{19}$ The synthesis of Morita-Baylis-Hillman adducts in the absence of chiral auxiliaries results in stereomeric mixtures of products. Kinetic resolution can be employed to obtain optically pure or enriched molecules therefrom. ${ }^{20-22}$ The use of enzymes for the kinetic resolution of secondary carbinols is well documented, ${ }^{23,24}$ and has proved to be economically and environmentally advantageous. Previous studies regarding biocatalytic resolution of enantiomers of 3(RS)-hydroxy-2methylenebutanenitrile $\mathbf{1}(\boldsymbol{R S})$ were focused on the optimization of transesterification reaction conditions using lipase from Pseudomonas cepacia. ${ }^{25}$ The optimized reaction conditions resulted in a moderate conversion of $\mathrm{MBH}$ adduct (27\%) with excellent ee (98\%). A major disadvantage of this procedure is the very long reaction time $(474 \mathrm{~h})$, which makes it unpractical. Rotation of the plane of polarized light of the acetylated product was described as levorotary but the specific rotatory power was not determined. Adduct $\mathbf{1}(\boldsymbol{R S})$ was also used to study nitrile hydrolase activity of Rhodococcus erythropolis SET1. ${ }^{26}$ The yield of recovered nitrile and reaction time were satisfactory ( $42 \%$ and $48 \mathrm{~h}$ respectively); ee was moderate $(76.5 \%)$. The configuration of the stereogenic secondary carbinol center was assigned only tentatively $(R)$, and the specific rotatory power also was not determined.

The aim of studies presented herein was to optimize the synthesis and biocatalytic kinetic resolution of racemic aliphatic $\mathrm{MBH}$ adduct to give optically pure model $\beta$-hydroxy-nitriles and their acetates. In addition, we aimed to determine the absolute configuration of the 3-hydroxy-2-methylenebutanenitrile.

\section{Results and Discussion}

3(RS)-Hydroxy-2-methylenebutanenitrile $\mathbf{1}(\boldsymbol{R S})$ was prepared by the Morita-Baylis-Hillman reaction of acetaldehyde and acrylonitrile using 1,4-diazabicyclo[2.2.2]octane (DABCO) as a catalyst (Scheme 2). 


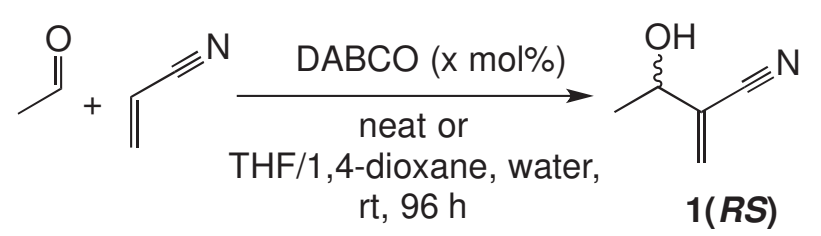

Scheme 2. Synthesis of the model racemic $\mathrm{MBH}$ adduct.

Optimization of the reaction conditions was carried out in a solvent-free environment (Table 1), and in THF, 1,4-dioxane, and their water mixtures (Table 2). An accelerated rate and increased yields in the MoritaBaylis-Hillman reaction of acetaldehyde and acrylonitrile was observed, as in previous reports regarding aromatic aldehydes and activated alkenes. ${ }^{18,27}$ In general, a stoichiometric amount of a base is usually used for $\mathrm{MBH}$ transformations. In this report we show that an increase in the molar ratio of DABCO results in lower product yields (entries 1-4). Increasing the molar ratio of acetaldehyde is more favorable than of acrylonitrile, and results in higher yields and fewer side products (entries 5 and 6).

Table 1. Optimization of $\mathrm{MBH}$ reaction of acetaldehyde and acrylonitrile under solvent-free conditions

\begin{tabular}{ccccc}
\hline Entry & Acetaldehyde $^{\mathrm{a}}$ & Acrylonitrile $^{\mathrm{a}}$ & $\mathrm{DABCO}^{\mathrm{a}}$ & Yield $^{\mathrm{b}}(\%)$ \\
\hline 1 & 1 & 1 & 0.2 & 97 \\
2 & 1 & 1 & 0.5 & 93 \\
3 & 1 & 1 & 0.75 & 90 \\
4 & 1 & 1 & 1 & 77 \\
5 & 1 & 1.5 & 1 & 70 \\
6 & 1.5 & 1 & 1 & 84 \\
\hline
\end{tabular}

${ }^{\mathrm{a}}$ Molar ratio. ${ }^{\mathrm{b}}$ Isolated yield.

Optimization of the reaction conditions was also carried out in THF, 1,4-dioxane and their water mixtures using equimolar amounts of both substrates, and 20 mol\% DABCO. Yields of MBH transformations in pure solvents were moderate to poor (entries 1 and 4), but in their water mixtures reactions yields were excellent. Similar outcomes were obtained in the coupling of acetaldehyde and methyl acrylate in organic solvent-water systems. $^{28}$

Table 2. Optimization of $\mathrm{MBH}$ reaction of acetaldehyde and acrylonitrile carried out in THF, 1,4-dioxane, and their mixtures with water

\begin{tabular}{cccccccc}
\hline Entry & Acetaldehyde $^{\mathrm{a}}$ & Acrylonitrile $^{\mathrm{a}}$ & $\mathrm{DABCO}^{\mathrm{a}}$ & $\mathrm{THF}^{\mathrm{b}}$ & $\mathrm{H}_{2} \mathrm{O}^{\mathrm{b}}$ & 1,4-Dioxane $^{\mathrm{b}}$ & Yield $^{\mathrm{c}}(\%)$ \\
\hline 1 & 1 & 1 & 0.2 & 1 & - & - & 40 \\
2 & 1 & 1 & 0.2 & 1 & 1 & - & 77 \\
3 & 1 & 1 & 0.2 & 0.7 & 0.3 & - & 94 \\
4 & 1 & 1 & 0.2 & - & - & 1 & 19 \\
5 & 1 & 1 & 0.2 & - & 1 & 1 & 93 \\
6 & 1 & 1 & 0.2 & - & 0.3 & 0.7 & 91 \\
\hline
\end{tabular}

${ }^{a}$ Molar ratio. ${ }^{b}$ Volume ratio. ${ }^{c}$ Isolated yield. 
The first attempt at kinetic resolution of $\mathbf{1}(\boldsymbol{R S})$ was based on enzymatic transesterification (Scheme 3 ) under anhydrous conditions with vinyl acetate as an acyl donor. We chose ten lipases for the initial screening (Table 3). Entry numbers in Table 3 identify the enzymes used in Tables 4 and 5.

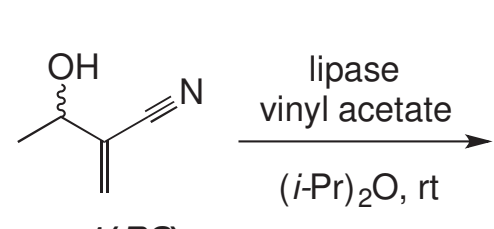

1(RS)

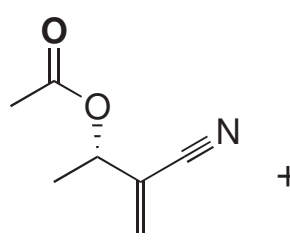

2(S)<smiles>C=C(C#N)C(C)O</smiles>

1(R)

Scheme 3. Enzymatic transesterification of 3(RS)-hydroxy-2-methylenebutanenitrile.

Table 3. Biocatalysts selected for the screening procedure

\begin{tabular}{cc}
\hline Entry & Lipase \\
\hline 1 & Novozyme 435 \\
2 & PS Amano lipase from Pseudomonas cepacia \\
3 & Immobilized lipozyme from Mucor miehei \\
4 & Lipase from Rhizopus oryzae \\
5 & G Amano lipase from Penicillium camemberti \\
6 & AYS Amano lipase \\
7 & AS Amano lipase \\
8 & Lipase A from Candida antarctica \\
9 & RMIM lipozyme \\
10 & M Amano lipase from Mucor javanicus \\
\hline
\end{tabular}

Table 4. Results of biocatalytic transesterification of 3(RS)-hydroxy-2-methylenebutanenitrile

\begin{tabular}{|c|c|c|c|c|c|c|c|c|c|c|c|c|}
\hline \multirow[b]{2}{*}{ Entry } & \multicolumn{3}{|c|}{$1 \mathrm{~h}$} & \multirow[b]{2}{*}{$E^{d}$} & \multicolumn{3}{|c|}{$24 \mathrm{~h}$} & \multirow[b]{2}{*}{$E^{d}$} & \multicolumn{3}{|c|}{$48 \mathrm{~h}$} & \multirow[b]{2}{*}{$E^{d}$} \\
\hline & $\begin{array}{l}\text { Alc. }^{a} \\
e e \%\end{array}$ & $\begin{array}{c}\text { Acetate }^{\mathrm{b}} \\
\text { ee\% }\end{array}$ & $\begin{array}{c}\text { Conv. }^{c} \\
\%\end{array}$ & & $\begin{array}{l}\text { Alc. }^{a} \\
e e^{\circ}\end{array}$ & $\begin{array}{c}\text { Acetate }^{b} \\
e e \%\end{array}$ & $\begin{array}{c}\text { Conv. }^{\mathrm{c}} \\
\%\end{array}$ & & $\begin{array}{l}\text { Alc. }^{a} \\
e e^{\circ}\end{array}$ & $\begin{array}{c}\text { Acetate }^{b} \\
e e \%\end{array}$ & $\begin{array}{c}\text { Conv. }^{c} \\
\%\end{array}$ & \\
\hline 1 & 33 & 97 & 25 & 91 & 63 & 82 & 44 & 19 & 29 & 60 & 32 & 5 \\
\hline 2 & 9 & 100 & 9 & - & 19 & 96 & 17 & 59 & 48 & 96 & 33 & 79 \\
\hline 3 & 5 & 100 & 4 & - & 54 & 95 & 36 & 67 & 81 & 94 & 46 & 81 \\
\hline 4 & 0 & 0 & - & - & 0 & 0 & - & - & 0 & 0 & - & - \\
\hline 5 & 0 & 0 & - & - & 0 & 0 & - & - & 0 & 0 & - & - \\
\hline 6 & 0 & 0 & - & - & 1 & 100 & 1 & - & 3 & 63 & 4 & 5 \\
\hline 7 & 0 & 0 & - & - & 1 & 100 & 1 & - & 2 & 86 & 3 & 14 \\
\hline 8 & 61 & 95 & 39 & 73 & 87 & 44 & 67 & 7 & 73 & 29 & 71 & 4 \\
\hline 9 & 1 & 100 & 1 & - & 18 & 96 & 15 & 58 & 26 & 96 & 21 & 63 \\
\hline 10 & 0 & 0 & - & - & 0 & 0 & - & - & 1 & 100 & $<1$ & - \\
\hline
\end{tabular}

${ }^{a}(R)$-acetate. ${ }^{b}(S)$-alcohol. ${ }^{c}$ Based on GC, calculated according to the formula conv. $=e e_{s} /\left(e e_{s}+e e_{p}\right) \cdot{ }^{d}$ E-value calculated according to the formula $\mathrm{E}=\left\{\ln \left[\left(1-e e_{s}\right) /\left(1+e e_{s} / e e_{p}\right)\right]\right\} /\left\{\ln \left[\left(1+e e_{s}\right) /\left(1+e e_{s} / e e_{p}\right)\right]\right\}$ 
As a result of these biotransformations we were able to obtain acetate $\mathbf{2}(\boldsymbol{S})$ in excellent enantiomeric excess, and moderate to very good yield (Table 4, entries 1-3 and 8). Novozyme 435 and lipase A from Candida antarctica transformed S-alcohol most rapidly (Table 4 entries 1 and 8; 25\% and 39\% of substrate conversion after $1 \mathrm{~h}$ ). PS Amano lipase from Pseudomonas cepacia and immobilized lipozyme from Mucor miehei required more time to achieve higher conversion, and in these cases there was little or no effect on enantioselectivity.

The second strategy for obtaining pure enantiomers of 3-hydroxy-2-methylenebutanenitrile was enzymatic hydrolysis of $\mathbf{3}(R S)$-acetoxy-2-methylenebutanenitrile $\mathbf{2}(\boldsymbol{R S})$, which was synthesized from $\mathbf{1}(\boldsymbol{R S})$ using acetyl chloride and pyridine in anhydrous dichloromethane (Scheme 4). Both compounds were found to be not useful as fragrances: alcohol $\mathbf{1}(\boldsymbol{R S})$ is odorless, and acetate $\mathbf{2}(\boldsymbol{R S})$ causes irritation to the nasal mucosa. Biotransformations were carried out using the same set of enzymes at room temperature with shaking (150 $\mathrm{rpm}$ ) in a biphasic system consisting of a phosphate buffer ( $\mathrm{pH} 7)$ and $i-\mathrm{Pr}_{2} \mathrm{O}$ (Scheme 4).

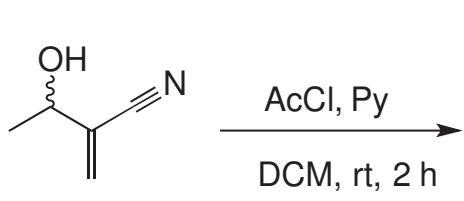

$1(R S)$

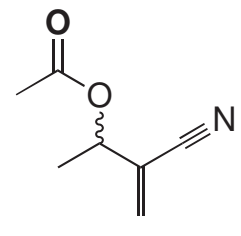

2(RS)

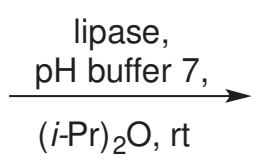

$(i-\mathrm{Pr})_{2} \mathrm{O}, \mathrm{rt}$

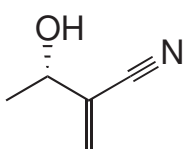

1(S)

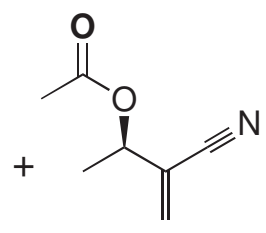

2(R)

Scheme 4. Synthesis and enzymatic hydrolysis of 3(RS)-acetoxy-2-methylenebutanenitrile.

The three tested enzymes gave acceptable results (Table 5, entries 1,2 and 8). It can be seen that enzymatic hydrolysis results in higher conversions than transesterification reactions, but at the expense of enantioselectivity. The $(S)$-acetate is consumed considerably faster than the $R$-isomer, but the hydrolysis in a biphasic system is a slower process, and in this case it requires $24 \mathrm{~h}$ to obtain excellent ees of an acetate (>99\%). Conversions above 50\% indicate that both isomers of acetate $\mathbf{2}$ are being consumed. Careful monitoring of the hydrolysis progress is required to obtain optically pure $\mathbf{1}(S)$.

Table 5. Results of biocatalytic hydrolysis of 3(RS)-acetoxy-2-methylenebutanenitrile

\begin{tabular}{|c|c|c|c|c|c|c|c|c|c|c|c|c|}
\hline \multirow[b]{2}{*}{ Entry } & \multicolumn{3}{|c|}{$1 \mathrm{~h}$} & \multirow[b]{2}{*}{$E^{d}$} & \multicolumn{3}{|c|}{$24 \mathrm{~h}$} & \multirow[b]{2}{*}{$E^{d}$} & \multicolumn{3}{|c|}{$48 \mathrm{~h}$} & \multirow[b]{2}{*}{$E^{d}$} \\
\hline & $\begin{array}{c}\text { Acetate }^{\mathrm{a}} \\
e e \%\end{array}$ & $\begin{array}{l}\text { Alc. }^{b} \\
e e \%\end{array}$ & $\begin{array}{c}\text { Conv. }^{c} \\
\%\end{array}$ & & $\begin{array}{c}\text { Acetate }^{a} \\
e e \%\end{array}$ & $\begin{array}{l}\text { Alc. }^{b} \\
e e \%\end{array}$ & $\begin{array}{c}\text { Conv. }^{\mathrm{c}} \\
\%\end{array}$ & & $\begin{array}{c}\text { Acetate }^{a} \\
e e \%\end{array}$ & $\begin{array}{l}\text { Alc. } \\
e e^{b}\end{array}$ & $\begin{array}{c}\text { Conv. }^{\mathrm{c}} \\
\%\end{array}$ & \\
\hline 1 & 66 & 100 & 40 & $>200$ & 100 & 71 & 58 & 30 & 100 & 54 & 65 & 16 \\
\hline 2 & 23 & 100 & 19 & $>200$ & 100 & 84 & 54 & 59 & 100 & 78 & 56 & 41 \\
\hline 3 & 0 & 0 & - & - & 0 & 0 & - & - & 3 & 100 & 3 & - \\
\hline 4 & 0 & 0 & - & - & 0 & 0 & - & - & 1 & 11 & 8 & - \\
\hline 5 & 0 & 0 & - & - & 0 & 0 & - & - & 0 & 0 & - & - \\
\hline 6 & 1 & 100 & 1 & - & 39 & 54 & 42 & 5 & 60 & 47 & 56 & 5 \\
\hline 7 & 3 & 27 & 10 & 2 & 86 & 5 & 95 & 2 & 100 & 2 & 98 & 3 \\
\hline 8 & 87 & 100 & 47 & $>200$ & 100 & 49 & 67 & 14 & 100 & 33 & 75 & 9 \\
\hline 9 & 0 & 0 & - & - & 0 & 0 & - & - & 0 & 0 & - & - \\
\hline 10 & 0 & 0 & - & - & 0 & 0 & - & - & 0 & 0 & - & - \\
\hline
\end{tabular}

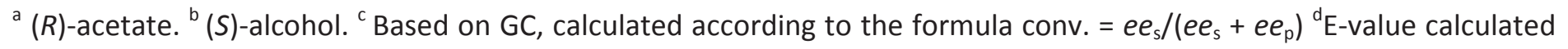
according to the formula $\mathrm{E}=\left\{\ln \left[\left(1-e e_{s}\right) /\left(1+e e_{s} / e e_{p}\right)\right]\right\} /\left\{\ln \left[\left(1+e e_{s}\right) /\left(1+e e_{s} / e e_{p}\right)\right]\right\}$ 
The last phase of this study was determination of the absolute configuration of enantiomers of the Morita-Baylis-Hillman adduct 1 . We chose the Mosher ester method. ${ }^{29}$ Optically pure acetate obtained via enzymatic hydrolysis (intact substrate, Table 5 entry 2, $24 \mathrm{~h}$ ) was hydrolyzed chemically in a biphasic system. Subsequent esterification with both enantiomers of Mosher's acid chloride in anhydrous conditions gave two esters $\mathbf{3}(\boldsymbol{R}, \boldsymbol{R})$ and $\mathbf{3}(\boldsymbol{S}, \boldsymbol{R})$ (Scheme 5$)$.

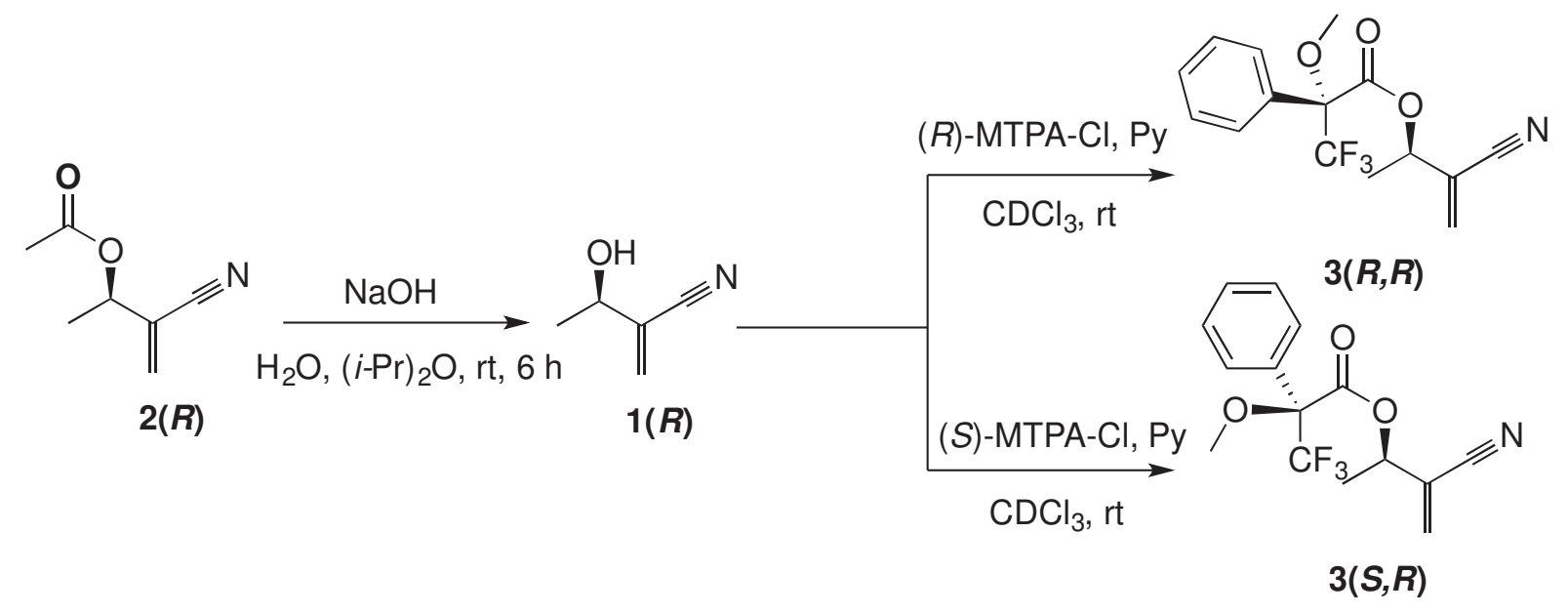

Scheme 5. Synthesis of Mosher's esters from the enzymatic hydrolysis product.

All relevant chemical shifts of Mosher's esters are shown in Table 6.

Table 6. Chemical shifts of $\mathbf{3}(R, R)$ and $3(S, R)$

\begin{tabular}{ccc}
\hline Group & $\begin{array}{c}\delta_{(S) \text {-ester }} \\
{[\mathrm{ppm}]}\end{array}$ & $\begin{array}{c}\boldsymbol{\delta}_{(R) \text {-ester }} \\
{[\mathrm{ppm}]}\end{array}$ \\
\hline Methylene H & 5.96 & 6.03 \\
Methylene H & 5.94 & 6.01 \\
Methanetriyl H & 5.57 & 5.56 \\
Methyl H & 1.50 & 1.43 \\
\hline
\end{tabular}

Methyl and methanetriyl hydrogens of the $(S)$-ester lie downfield with respect to peaks of the $(R)$-ester, and methylene hydrogens the opposite. This shielding/deshielding pattern (Figure 1) indicates that initial alcohol has the $R$ configuration. 

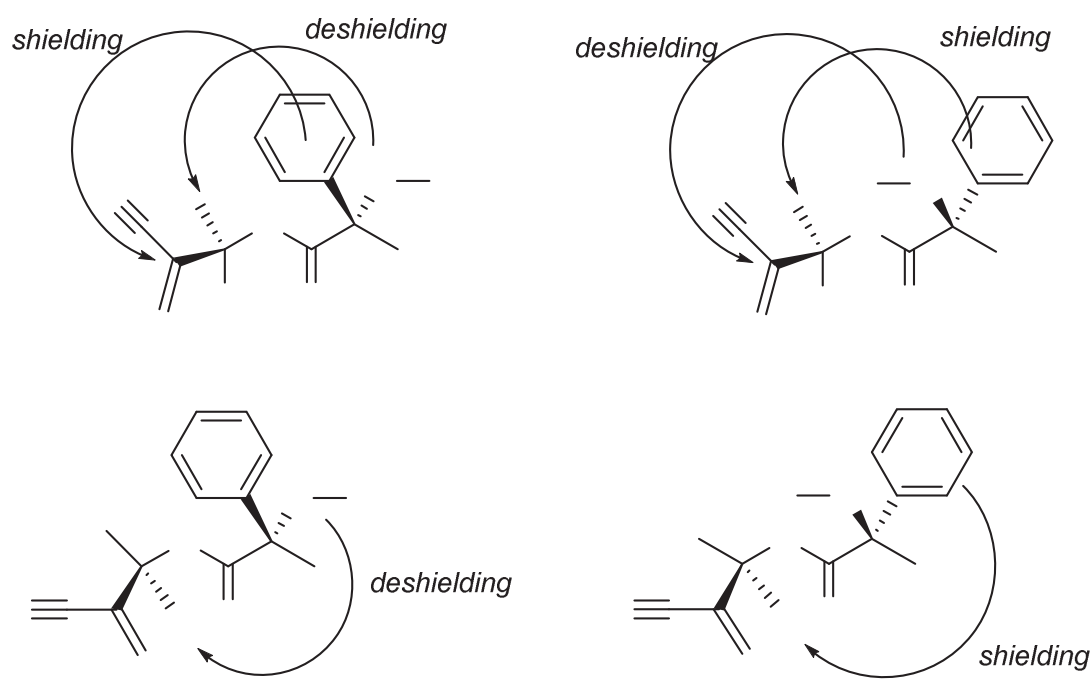

Figure 1. Shielding/deshielding pattern for Mosher's esters of $\mathbf{1}(\boldsymbol{R})$

\section{Conclusion}

We report above the strategy of the synthesis of the multifunctional building block 3-hydroxy-2-methylenebutanenitrile 1, its kinetic resolution into optically pure isomers, and determination of the absolute configuration of the isomers of the title compound. Solvent-free Morita-Baylis-Hillman reaction has proven to give the best results (Table 1 entry 1 ). Two strategies of kinetic resolution allowed us to obtain the $(S)$-acetate with excellent ee (97\% enzymatic transesterification - Table 4 entry 1$)$, and optically pure (S)-alcohol (>99\% Table 5 entry 1 ) and $(R)$-acetate (>99\% - Table 5 entries 1,2 and 8). The absolute configuration of the enzymatic hydrolysis product (Scheme 5 ) was determined by Mosher's method; the shielding/deshielding pattern indicates that the initial alcohol has the $R$ configuration.

\section{Experimental Section}

General. All reagents obtained from commercial suppliers (Sigma-Aldrich, Poznań, Poland; Merck, Warszawa, Poland; Avantor, Gliwice, Poland) were of analytical grade and were used without further purification. The course of all reactions, composition of products, and their purities were monitored by gas chromatography (GC). Analytical GC was performed on Agilent 7890A apparatus with flame ionization detector with nitrogen as make up gas. Analyses were carried out on Thermo TR-5 column [(5\% phenyl)-methylpolysiloxane] $30 \mathrm{~m} \times 0.32$ $\mathrm{mm}$ ID $\times 1.0 \mu \mathrm{m}$ film using helium as carrier gas at a flow rate of $3.8462 \mathrm{~mL} / \mathrm{min}$ in a split ratio of 1:100 and the following programme: (a) $40{ }^{\circ} \mathrm{C}$ for $5 \mathrm{~min}$; (b) rate of $10.0^{\circ} \mathrm{C} / \mathrm{min}$ from 40 to $190{ }^{\circ} \mathrm{C}$ and hold for $5 \mathrm{~min}$. Chiral gas chromatography was carried out with Varian CP Chirasil-Dex CB column, $25 \mathrm{~m} \times 0.25 \mathrm{~mm}$ ID x $0.25 \mu \mathrm{m}$ film. Analyses were carried out using helium as carrier gas, flow $0.5 \mathrm{~mL} / \mathrm{min}$, split ratio 35:1 with programme: (a) $120{ }^{\circ} \mathrm{C}$ for $10 \mathrm{~min}$. Injector and detector were held at $250{ }^{\circ} \mathrm{C}$. Injector and detector were held at $250{ }^{\circ} \mathrm{C}$. High resolution mass spectra (HRMS) were recorded using electron spray ionization (ESI) technique on Waters LCT Premier XE mass spectrometer. The middle-infrared spectra $\left(4000-400 \mathrm{~cm}^{-1}\right)$ were collected on a Fourier transform, Bruker VERTEX $70 \mathrm{~V}$ vacuum spectrometer equipped with an air-cooled DTGS detector (Ettlingen, Germany). The liquid samples were placed on the diamond crystal of the ATR accessory. The spectral data 
were recorded at a resolution of $2 \mathrm{~cm}^{-1}$ with 64 scans collection and further elaborated using Bruker OPUS software. ${ }^{1} \mathrm{H}$ and ${ }^{13} \mathrm{C}$ NMR spectra were recorded in $\mathrm{CDCl}_{3}$ with TMS as an internal standard on Bruker Avance TM DRX 600 instrument. Chemical shifts $(\delta)$ are reported in ppm and coupling constants $(J)$ are given in $\mathrm{Hz}$. Optical rotation measurements were carried out on a Krüss P3000 automatic polarimeter.

\section{3(RS)-Hydroxy-2-methylenebutanenitrile (1(RS))}

To a mixture of acetaldehyde $(5 \mathrm{~g}, 6.35 \mathrm{~mL}, 0.11 \mathrm{~mol})$ and acrylonitrile $(5.8 \mathrm{~g}, 7.2 \mathrm{~mL}, 0.11 \mathrm{~mol})$ was added DABCO (2.5 g, $22 \mathrm{mmol})$. After stirring for $96 \mathrm{~h}$ at $\mathrm{rt}$, the reaction mixture was diluted with $100 \mathrm{~mL}$ of EtOAc. The organic layer was washed three times with $5 \%$ water solution of $\mathrm{HCl}$, once with water, once with $10 \%$ water solution of $\mathrm{NaHCO}_{3}$, and then with brine, dried over $\mathrm{Na}_{2} \mathrm{SO}_{4}$ and filtered. Evaporation of the solvents gave a yellow liquid, which was purified through flash chromatography on silica gel (hexane/EtOAc from 0 to $20 \% \mathrm{EtOAc}$ ) to give 3(RS)-hydroxy-2-methylenebutanenitrile $\mathbf{1}(\boldsymbol{R S})$ as a colorless, odorless liquid $(10.4 \mathrm{~g}, 97 \%)$. IR (ATR, $\left.v_{\text {max }}, \mathrm{cm}^{-1}\right): 3465(\mathrm{br}), 2235$ (w). ${ }^{1} \mathrm{H}$ NMR $\left(600 \mathrm{MHz}, \mathrm{CDCl}_{3}\right): \delta_{\mathrm{H}} 1.47\left(3 \mathrm{H}, \mathrm{d},{ }^{3} \mathrm{~J}_{\mathrm{HH}} 6.6 \mathrm{~Hz},-\mathrm{CH}_{3}\right), 2.08(1 \mathrm{H}, \mathrm{s}$, $-\mathrm{OH}), 4.47\left(1 \mathrm{H}, \mathrm{q},{ }^{3} J_{H H} 6.6 \mathrm{~Hz},-\mathrm{CH}\right), 5.98$ and $6.04\left(2 \mathrm{H}, 2 \mathrm{x} \mathrm{d},{ }^{4} J_{H H} 0.6 \mathrm{~Hz}, \mathrm{CH} \times 2\right.$ olefinic) ${ }^{13} \mathrm{C} \mathrm{NMR}\left(\mathrm{CDCl}_{3}, 150\right.$ $\mathrm{MHz}): \delta_{\mathrm{C}} 22.3\left(\mathrm{CH}_{3}\right), 68.3\left(\mathrm{CH}_{3} \underline{\mathrm{CHC}}\right), 117.1\left(\mathrm{CHC}_{\mathrm{CH}}\right), 127.8\left(\mathrm{CH}_{\underline{C} C H}\right), 129.1(\mathrm{CHC} \underline{\mathrm{CN}}), \mathrm{HRMS}(\mathrm{TOFMS} \mathrm{EI+)} \mathrm{m} / \mathrm{z}$ calculated $\left[\mathrm{C}_{5} \mathrm{H}_{7} \mathrm{NO}+\mathrm{H}^{+}\right]$98.0600, found 98.0615

\section{General procedure for enzymatic transesterification of $1(R S)$}

Vinyl acetate (42 mg, $45 \mu \mathrm{L}, 0.49 \mathrm{mmol}$ ) and $\mathrm{MBH}$ adduct $\mathbf{1}(\boldsymbol{R S})(25 \mathrm{mg}, 0.26 \mathrm{mmol})$ were placed in a $5 \mathrm{~mL}$ glass vial and dissolved in $2 \mathrm{~mL}$ of anhydrous $i-\mathrm{Pr}_{2} \mathrm{O}$. A lipase $(20 \mathrm{mg})$ was added, and reaction was stirred for $46 \mathrm{~h}$. $200 \mu \mathrm{l}$ of reaction mixture was collected after $1 \mathrm{~h}, 24 \mathrm{~h}$ and $48 \mathrm{~h}$, and subjected to chiral gas chromatographic analysis.

3(RS)-Acetoxy-2-methylenebutanenitrile (2(RS)). Acetyl chloride $(4.04 \mathrm{~g}, 3.67 \mathrm{~mL}, 51.5 \mathrm{mmol})$ was added dropwise to a mixture of 3(RS)-hydroxy-2-methylenebutanenitrile $\mathbf{1}(R S)$ (5 g, $51.5 \mathrm{mmol}$ ) and pyridine (4.1 g, $4.2 \mathrm{~mL}, 51.5 \mathrm{mmol}$ ) in $100 \mathrm{~mL}$ of $\mathrm{DCM}$ at $0{ }^{\circ} \mathrm{C}$. The reaction was stirred for additional $2 \mathrm{~h}$ at rt. The reaction mixture was diluted with $50 \mathrm{~mL}$ of DCM. The organic layer was washed three times with $5 \%$ water solution of $\mathrm{HCl}$, once with water, once with $10 \%$ water solution of $\mathrm{NaHCO}_{3}$, and then with brine, dried over $\mathrm{Na}_{2} \mathrm{SO}_{4}$ and filtered. Evaporation of the solvents gave a yellow liquid, which was purified through flash chromatography on silica gel (hexane/EtOAc from 0 to $10 \%$ EtOAc) to give 3(RS)-acetoxy-2-methylenebutanenitrile $2(R S)$ as a colorless liquid, irritating to nasal mucosa (6.2 g, 86\%). IR (ATR, $v_{\max }, \mathrm{cm}^{-1}$ ): $2227(\mathrm{w}), 1743$ (s). ${ }^{1} \mathrm{H}$ NMR (600 $\left.\mathrm{MHz}, \mathrm{CDCl}_{3}\right): \delta_{\mathrm{H}} 1.49\left(3 \mathrm{H}, \mathrm{d},{ }^{3} \mathrm{~J}_{\mathrm{HH}} 6.6 \mathrm{~Hz}, \mathrm{CHCH}_{3}\right), 2.13\left(3 \mathrm{H}, \mathrm{s}, \mathrm{COCH}_{3}\right), 5.44\left(1 \mathrm{H}, \mathrm{q}^{3}{ }^{3} \mathrm{JHH}_{\mathrm{H}} 6.6 \mathrm{~Hz}, \mathrm{CH}\right), 6.03$ and 6.05 $\left(2 \mathrm{H}, 2 \times \mathrm{d},{ }^{4} J_{H H} 0.6 \mathrm{~Hz}, \mathrm{CH} \times 2\right.$ olefinic) ${ }^{13} \mathrm{C} \mathrm{NMR}\left(\mathrm{CDCl}_{3}, 150 \mathrm{MHz}\right): \delta_{\mathrm{C}} 19.2\left(\underline{\mathrm{CH}}_{3} \mathrm{CO}\right), 21.0\left(\mathrm{CH}_{\underline{C}} \mathrm{H}_{3}\right), 69.5\left(\mathrm{CH}{ }_{3} \underline{\mathrm{CHC}}\right)$, $116.2\left(\mathrm{CHCCH}_{2}\right), 123.8\left(\mathrm{CH}_{\underline{C} C H}\right), 131.7$ (CHCCN), $169.7\left(\mathrm{CH}_{3} \underline{\mathrm{CO}}\right) \mathrm{HRMS}\left(\right.$ TOFMS El+) $\mathrm{m} / z$ calculated $\left[\mathrm{C}_{7} \mathrm{H}_{9} \mathrm{NO}_{2}+\right.$ $\left.\mathrm{H}^{+}\right]$140.0706, found 140.0720

General procedure for enzymatic hydrolysis of $\mathbf{2}(\boldsymbol{R S})$. Acetate $\mathbf{2}(\boldsymbol{R S})(25 \mathrm{mg}, 0.18 \mathrm{mmol})$ was placed in a $10 \mathrm{~mL}$ glass vial and dissolved in $2 \mathrm{~mL}$ of $i-\mathrm{Pr}_{2} \mathrm{O}$. A lipase $(20 \mathrm{mg})$ and $2 \mathrm{~mL}$ of distilled water were added, and reaction was stirred for 46 h. $200 \mu$ l of reaction mixture was collected after 1 h, 24 h and 48 h, and subjected to chiral gas chromatographic analysis.

$(-)-3(R)$-Acetoxy-2-methylenebutanenitrile (2(R)). Acetate $2(\boldsymbol{R S})(800 \mathrm{mg}, 5.76 \mathrm{mmol})$ was placed in a $20 \mathrm{~mL}$ glass vial and dissolved in $5 \mathrm{~mL}$ of $i$ - $\mathrm{Pr}_{2} \mathrm{O}$. PS Amano lipase from Pseudomonas cepacia (500 $\mathrm{mg}$ ) and $5 \mathrm{~mL}$ of distilled water were added, and reaction was stirred for $24 \mathrm{~h}$. Lipase was filtered off, phases were separated, and the water phase was extracted twice with $2 \mathrm{~mL}$ of $i-\mathrm{Pr}_{2} \mathrm{O}$. The combined organic phases were dried over $\mathrm{Na}_{2} \mathrm{SO}_{4}$ and filtered. Evaporation of the solvents gave a colorless liquid, which was purified through flash 
chromatography on silica gel (hexane/EtOAc from 0 to $10 \%$ EtOAc) to give (?)-3-(R)-acetoxy-2methylenebutanenitrile $\mathbf{2}(\boldsymbol{R})$ as a colorless liquid, irritating to nasal mucosa (100 $\mathrm{mg}, 25 \%)$. $[\alpha]^{24}=-90[1.0$, $\left.\mathrm{CHCl}_{3}\right], \mathrm{NMR}$ spectra correspond with the spectra of the racemic form.

\section{Monitoring the progress of kinetic resolution}

Biocatalytic transesterifications and hydrolysis were monitored via chiral gas chromatography under conditions described in the experimental "general" section. Determination of absolute configuration of the enzymatic hydrolysis product provided the possibility to identify respective isomers: $\mathrm{R}_{\mathrm{t}}=5.39 \mathrm{~min}((R)$ acetate); $\mathrm{R}_{\mathrm{t}}=5.72 \mathrm{~min}\left((S)\right.$-acetate); $\mathrm{R}_{\mathrm{t}}=8.41 \mathrm{~min}\left((S)\right.$-alcohol); $\mathrm{R}_{\mathrm{t}}=8.74 \mathrm{~min}((R)$-alcohol).

$(-)-3(R)$-Hydroxy-2-methylenebutanenitrile $(\mathbf{1}(\boldsymbol{R}))$. Acetate $\mathbf{2}(\boldsymbol{R})(100 \mathrm{mg}, 0.72 \mathrm{mmol})$ was placed in a $10 \mathrm{~mL}$ glass vial and dissolved in $3 \mathrm{~mL}$ of $i$ - $\mathrm{Pr}_{2} \mathrm{O}$. A solution of $\mathrm{NaOH}(\sim 60 \mathrm{mg}, \sim 1.44 \mathrm{mmol})$ in $3 \mathrm{~mL}$ of distilled water was added, and reaction was stirred for $6 \mathrm{~h}$. After this time phases were separated, and the water phase was extracted twice with $2 \mathrm{~mL}$ of $i-\mathrm{Pr}_{2} \mathrm{O}$. The combined organic phases were dried over $\mathrm{Na}_{2} \mathrm{SO}_{4}$ and filtered. Evaporation of the solvents gave a pure (鴫)-3-(R)-hydroxy-2-methylenebutanenitrile $\mathbf{2}(\boldsymbol{R})$ as a colorless and odorless liquid $(65 \mathrm{mg}, 92 \%) .[\alpha]^{24}=-10\left[0.65, \mathrm{CHCl}_{3}\right]$, NMR spectra correspond with the spectra of the racemic form.

General procedure for Mosher's esters preparation ${ }^{29}$. Mosher's acid chloride (3,3,3-trifluoro-2-methoxy-2phenylpropanoic acid chloride, $3 \mu \mathrm{L}, 15.6 \mu \mathrm{mol})$ was added to a mixture of 3(R)-hydroxy-2methylenebutanenitrile $\mathbf{1}(\boldsymbol{R})(1 \mathrm{mg}, 10.3 \mu \mathrm{mol})$ and dry pyridine $(2 \mu \mathrm{L}, 25 \mu \mathrm{mol})$ in $300 \mu \mathrm{L}$ of $\mathrm{CDCl}_{3}$. The reaction mixture was stirred until completion ( $2 \mathrm{~h}$, TLC: hexane/EtOAc 4:1) then diluted with $300 \mu \mathrm{L}$ of $\mathrm{CDCl}_{3}$. 2(R)-3-Cyanobut-3-en-2-yl 2(S)-3,3,3-trifluoro-2-methoxy-2-phenylpropanoate $(3(S, R)) .{ }^{1} \mathrm{H} \mathrm{NMR}(600 \mathrm{MHz}$, $\left.\mathrm{CDCl}_{3}\right): \delta_{\mathrm{H}} 1.43\left(3 \mathrm{H}, \mathrm{d},{ }^{3} J_{H H} 6.6 \mathrm{~Hz},-\mathrm{CH}_{3}\right), 3.35\left(3 \mathrm{H}, \mathrm{s},-\mathrm{OCH}_{3}\right), 5.56\left(1 \mathrm{H}, \mathrm{q},{ }^{3} J_{H H} 6.6 \mathrm{~Hz},-\mathrm{CH}\right), 6.01$ and $6.03(2 \mathrm{H}, 2 \mathrm{x}$ d, ${ }^{4} J_{H H} 0.6 \mathrm{~Hz}, \mathrm{CH} \times 2$ olefinic), 7.28-7.36 (5H, m, aromatic)

2(R)-3-Cyanobut-3-en-2-yl 2(R)-3,3,3-trifluoro-2-methoxy-2-phenylpropanoate $(\mathbf{3}(\boldsymbol{R}, \boldsymbol{R})) .{ }^{1} \mathrm{H} \mathrm{NMR}(600 \mathrm{MHz}$, $\left.\mathrm{CDCl}_{3}\right): \delta_{\mathrm{H}} 1.50\left(3 \mathrm{H}, \mathrm{d},{ }^{3} \mathrm{~J}_{\mathrm{HH}} 6.6 \mathrm{~Hz},-\mathrm{CH}_{3}\right), 3.35\left(3 \mathrm{H}, \mathrm{s},-\mathrm{OCH}_{3}\right), 5.57\left(1 \mathrm{H}, \mathrm{q},{ }^{3} J_{H H} 6.6 \mathrm{~Hz},-\mathrm{CH}\right), 5.94$ and $5.96(2 \mathrm{H}, 2 \mathrm{x}$ d, ${ }^{4} J_{H H} 0.6 \mathrm{~Hz}, \mathrm{CH} \times 2$ olefinic), 7.28-7.40 (5H, m, aromatic)

\section{Acknowledgements}

This work was financed by Wrocław Centre of Biotechnology, programme The Leading National Research Centre (KNOW) for years 2014-2018.

\section{References}

1. Wei, Y.; Shi, M. Chem. Rev. 2013, 113, 6659.

http://dx.doi.org/10.1021/cr300192h

2. Lei, Z.-Y.; Liu, X.-G.; Shi, M.; Zhao, M. Tetrahedron: Asymmetry 2008, 19, 2058.

http://dx.doi.org/10.1016/j.tetasy.2008.08.019

3. Yuan, K.; Song, H.-L.; Hu, Y.; Fang, J.-F.; Wu, X.-Y. Tetrahedron: Asymmetry 2010, 21, 903. http://dx.doi.org/10.1016/j.tetasy.2010.04.061

4. Wei, Y.; Shi, M. Acc. Chem. Res. 2010, 43, 1005. 
http://dx.doi.org/10.1021/ar900271g

5. McDougal, N. T.; Schaus, S. E. J. Am. Chem. Soc. 2003, 125, 12094.

http://dx.doi.org/10.1021/ja037705w

6. Berkessel, A.; Roland, K.; Neudörfl, J. M. Org. Lett. 2006, 8, 4195.

http://dx.doi.org/10.1021/ol061298m

7. Shi, M.; Liu, X.-G. Org. Lett. 2008, 10, 1043.

http://dx.doi.org/10.1021/ol7028806

8. Wang, J.; Li, H.; Yu, X.; Zu, L.; Wang, W. Org. Lett. 2005, 7, 4293.

http://dx.doi.org/10.1021/ol051822+

9. Jiang, L.; Yu, H.-w. Biotechnol. Lett. 2014, 36, 99.

http://dx.doi.org/10.1007/s10529-013-1329-9

10. Reetz, M. T.; Mondière, R.; Carballeira, J. D. Tetrahedron Lett. 2007, 48, 1679.

http://dx.doi.org/10.1016/j.tetlet.2007.01.063

11. Tian, X.; Zhang, S.; Zheng, L. Enzyme Microb. Tech. 2016, 84, 32.

http://dx.doi.org/10.1016/j.enzmictec.2015.12.006

12. Strub, D. J.; Kula, J.; Sikora, M.; Gibka, J.; Lochyński, S. Flavour Frag. J. 2016, 31, 81.

13. Siemieniuk, A.; Szałkowska-Pęgowska, H.; Lochyński, S.; Piątkowski, K.; Filipek, B.; Krupińska, J.;

Czarnecki, R.; Librowski, T.; Szymański, I. Pol. J. Pharmacol. Pharm. 1992, 44, 187.

14. Librowski, T.; Czarnecki, R.; Lochyński, S.; Frąckowiak, B.; Pasenkiewicz-Gierula, M.; Grochowski, J.; Serda,

P. Pol. J. Pharmacol. 2001, 53, 535.

http://dx.doi.org/10.1211/0022357011775640

15. Walkowicz, M.; Lochyński, S.; Walkowicz, C. Pol. J. Chem. 1981, 55, 135.

16. Hill, J. S.; Isaacs, N. S. Tetrahedron Lett. 1986, 27, 5007.

http://dx.doi.org/10.1016/S0040-4039(00)85119-9

17. Zhao, S.; He, M.; Guo, Z.; Zhou, N.; Wang, D.; Li, J.; Zhang, L. RSC Adv. 2015, 5, 32839.

http://dx.doi.org/10.1039/C5RA02102B

18. Saikia, M.; Sarma, J. C. Can. J. Chemistry 2010, 88, 1271.

http://dx.doi.org/10.1139/V10-133

19. Thoemel, F. H.: Eur. Pat. 0025939 B1. 1982.

20. Cho, C.-W.; Kong, J.-R.; Krische, M. J. Org. Lett. 2004, 6, 1337.

http://dx.doi.org/10.1021/ol049600j

21. Wang, Y.; Feng, X., Du, H. Org. Lett. 2011, 13, 4954.

http://dx.doi.org/10.1021/ol202069e

22. Trost, B. M.; Tsui, H.-C.; Toste, F. D. J. Am. Chem. Soc. 2000, 122, 3534.

http://dx.doi.org/10.1021/ja994326n

23. Klibanov, A. M. Acc. Chem. Res. 1990, 23, 114.

http://dx.doi.org/10.1021/ar00172a004

24. Ghanem, A.; Aboul-Enein, H. Y. Tetrahedron: Asymmetry 2004, 15, 3331.

http://dx.doi.org/10.1016/j.tetasy.2004.09.019

25. Bornscheuer, U.; Schapöhler, S.; Scheper, T.; Schügerl, K. Tetrahedron: Asymmetry 1991, 2, 1011. http://dx.doi.org/10.1016/S0957-4166(00)86150-9

26. Coady, T. M.; Coffey, L. V.; O'Reilly, C.; Lennon, C. M. Eur. J. Org. Chem. 2015, 2015, 1108.

27. Mack, J.; Shumba, M. Green Chem. 2007, 9, 328.

http://dx.doi.org/10.1039/B612983H 
28. Yu, C.; Liu, B.; Hu, L. J. Org. Chem. 2001, 66, 5413. http://dx.doi.org/10.1021/jo015628m

29. Hoye, T. R.; Jeffrey, C. S.; Shao, F. Nat. Protocols 2007, 2, 2451. http://dx.doi.org/10.1038/nprot.2007.354 